\title{
VARIATIONS IN SERUM CALCIUM AND PHOSPHORUS DURING PREGNANCY. IV. EFFECT ON THE BODY STORES AS SHOWN BY THE ASH OF RATS
}

\author{
By J. W. MULL \\ (From the Laboratory of the Maternity Hospital and the Department of Obstetrics, School of \\ Medicine, Western Reserve University, Cleveland)
}

(Received for publication May 18, 1936)

The evidence of a fall in the calcium and inorganic phosphorus content of the serum of normal pregnant women (1) served to confirm the general belief that the demands of pregnancy tended to exhaust the calcium and phosphorus resources of the body. A fall in the serum content, however, does not indicate whether the withdrawal is merely from the circulating medium or whether there is a corresponding depletion of the body stores. We have shown that, contrary to common belief, the teeth are not a source of supply (2). This is entirely logical, since there are no means by which the body could absorb calcium from them for use elsewhere. It is quite possible, on the other hand, for large amounts of mineral to be removed from the bones to meet an increased demand (3). Such a loss would be revealed by an examination of the calcium and phosphorus content of the body ash.

This study has been carried out on the rat, an animal small enough to be ashed with convenience, and with dietary habits that can be compared to those of man. The animals, of a good healthy stock, were maintained on a diet adequate in all respects, with no curtailment of either minerals or vitamins. Those sacrificed were anesthetized, bled to death from the carotid artery, and disemboweled. If pregnant, the uterus and young were removed together for separate examination. The blood was allowed to clot, the serum removed for analysis, and the clot returned to the carcass. The body was then weighed, dried for several days in an oven at 100 to $125^{\circ} \mathrm{C}$., and finally ashed in a silica dish. The ash was dissolved by warming in $10 \mathrm{ml}$. concentrated hydrochloric acid, previously saturated with tartaric acid; the excess acid was then evaporated off on a steam bath, and the remainder dissolved in 500 $\mathrm{ml}$. of distilled water. A small residue always settled out, but since tests showed this did not interfere with the determinations, it was, for convenience, allowed to remain undisturbed on the bottom of the flask. Since this was a study of the body resources, particular emphasis was laid on ashing the entire carcass, with the sole exception of the intestinal tract, which would contain unabsorbed minerals from the food.

Calcium determinations were made on small aliquots of the ash solution by the same method as used for blood in our previous work $(1,4,5)$. This method was satisfactorily checked at that time against gravimetric determinations. Multiple analyses on the same amounts of solution, the use of different amounts, and the recovery of added calcium all assured accuracy with this procedure. It was also used for the serum calcium, with the exception that the serum was weighed instead of measured by volume. This was more accurate in the instances where less than $2 \mathrm{ml}$. of serum was available, and also makes the result directly comparable with those of the ash.

Phosphorus was determined by the EmbdenFetter gravimetric method (6). This proved very satisfactory in our hands. It was simple, fast, and gave excellent recovery of known amounts of phosphorus, as well as good checks when different amounts of both material and reagent were used.

Four different conditions were studied, nonpregnant controls, a group 19 to 21 days pregnant, a newly delivered group, and one taken at the time of weaning. The controls were unbred animals of approximately the same age and weight as those having their first litter. The pregnant group were animals carrying their first or second litters. They were sacrificed just before delivery, when the young removed showed definite movement inside the uterus. The newly delivered group were sacrificed within 24 hours of the time their litters were dropped, but after the young had 
been cleaned up and the after-birth eaten by the mother. Those permitted to nurse their young were maintained until their offsprings, 21 to 24 days old, were able to eat and to take care of themselves, but had not ceased to nurse.

TABLE I

The calcium and phosphorus content of adult female rats

\begin{tabular}{|c|c|c|c|c|c|}
\hline & $\begin{array}{l}\text { Num- } \\
\text { ber of } \\
\text { rats }\end{array}$ & $\begin{array}{c}\text { Aver- } \\
\text { age } \\
\text { weight }\end{array}$ & \begin{tabular}{|c|} 
Cal- \\
cium \\
per \\
100 \\
grams \\
of \\
serum
\end{tabular} & $\begin{array}{c}\text { Cal- } \\
\text { cium } \\
\text { per } \\
\text { gram } \\
\text { of body } \\
\text { weight }\end{array}$ & $\begin{array}{l}\text { Phos- } \\
\text { phorus } \\
\text { per } \\
\text { gram } \\
\text { of } \\
\text { body } \\
\text { weight }\end{array}$ \\
\hline $\begin{array}{l}\text { Normal non-pregnant. } \\
19 \text { to } 21 \text { days pregnant. } \\
\text { Newly delivered....... } \\
\text { Nursed to weaning.... } \\
\text { Additional controls.... }\end{array}$ & $\begin{array}{r}10 \\
10 \\
5 \\
10 \\
8\end{array}$ & \begin{tabular}{|l|} 
grams \\
136.4 \\
172.0 \\
162.2 \\
140.0 \\
116.1
\end{tabular} & \begin{tabular}{|r|}
$m g m$. \\
10.04 \\
8.81 \\
10.16 \\
10.28 \\
10.28
\end{tabular} & $\begin{array}{l}m g m . \\
11.54 \\
10.83 \\
11.71 \\
11.58\end{array}$ & $\begin{array}{l}m g m . \\
7.32 \\
6.88 \\
7.07 \\
7.47\end{array}$ \\
\hline
\end{tabular}

The results from the adult animals are summarized in Table I. The serum calcium findings of the pregnant group, averaging greater in weight than the controls, show a fall of 12.2 per cent in calcium, while both the newly delivered and nursing groups show a slight rise, less than 3 per cent. The calcium per. gram of body weight, determined from the ash, of the pregnant group shows a 6.1 per cent fall from that of the normals, while the others show an insignificant rise, under 2 per cent. Similarly the pregnant animals show a 6 per cent loss in body phosphorus, while the newly delivered lost only 3.4 per cent, and the nursing group show a 2 per cent rise over the controls.

These serum calcium findings compare very well with those found in our study on pregnant women. In the human study the period of greatest depression occurred about six weeks before delivery, followed by a slight rise until delivery, then an abrupt return to normal. The 20th day of gestation in the rat is about the same proportion of the gestation period as the point six weeks prior to delivery is in the human. The recovery of the newly delivered animals, and the normal findings at the end of nursing, check very well with the available figures from the human series. With this close parallel in the serum calcium variations, it seems quite possible that the body stores, as represented by the ash, would show a similar parallel. This would indicate a real depression of the calcium and phosphorus resources of the body during pregnancy, especially in those cases where the serum calcium and phosphorus levels were markedly lowered.

This conclusion is supported by the metabolic studies of Macy, Hunscher, Nims, and McCosh (7) who found calcium losses in two of their three human subjects about 10 weeks before delivery. We are, however, apparently in disagreement with the calcium and phosphorus studies of Goss and Schmidt (8), carried out on rats. They found positive calcium and phosphorus balances during pregnancy, and negative balances during lactation. Our body ash analyses indicate just the reverse. They are, nevertheless, in agreement both with the definite recoveries of the serum calcium and phosphorus in our human series following delivery, and the work reported by Donelson, Nims, Hunscher, and Macy (9) showing positive calcium and phosphorus balances possible during lactation. If, though, the lactation has been of long duration, the calcium balance may become negative.

TABLE II

The calcium and phosphorus content of the young

\begin{tabular}{l|r|c|c|c|c}
\hline \hline & & $\begin{array}{c}\text { Num- } \\
\text { ber of } \\
\text { litters } \\
\text { age } \\
\text { num- } \\
\text { ber per- } \\
\text { litter }\end{array}$ & $\begin{array}{c}\text { Aver- } \\
\text { age } \\
\text { weight }\end{array}$ & $\begin{array}{c}\text { Cal- } \\
\text { cium } \\
\text { per } \\
\text { gram } \\
\text { of } \\
\text { body } \\
\text { weight }\end{array}$ & $\begin{array}{c}\text { Phos- } \\
\text { phorus } \\
\text { per } \\
\text { gram } \\
\text { of } \\
\text { body } \\
\text { weight }\end{array}$ \\
\hline Unborn young......... & 11 & 6.63 & 30.6 & 1.016 & 1.888 \\
New-born young....... & 6 & 6.66 & 34.9 & 2.195 & 2.698 \\
\hline
\end{tabular}

The young removed from the pregnant animals were ashed in with the uterus and placenta, in silica dishes, but were dissolved in only $5 \mathrm{ml}$. of acid, and made to a final volume of $50 \mathrm{ml}$. The new-born were treated in the same way, but only the clean young themselves were ashed. The results are given in Table II. The marked difference in calcium and phosphorus between the two groups can be explained, in part at least, by the fact that a portion of the weight of the unborn group was made up of placenta and uterus. The difference between the new-born and the adults, however, are particularly striking, the calcium content of the adults averaging almost 5 times that of the young, with the phosphorus almost 3 times. 
The calcium-phosphorus ratios are also worthy of note, those of the adults being roughly $11 / 7$ while in the young it is $2.2 / 2.7 \mathrm{mgm}$. per $1 \mathrm{gram}$ of body weight.

In view of the very low per cent of calcium and phosphorus in the body weight of the rat young, it is quite possible that considerable allowance should be made in attempting to project these findings to the conditions that pertain with the human mother. With the heavier human fetus containing 0.7 to 0.8 per cent calcium, or from 13 to 33 grams (10), the demands very probably are much greater in proportion, and an analysis of the maternal human ash would probably reveal a greater loss than the 6 per cent found in the rat.

\section{CONCLUSIONS}

Pregnant rats show a fall in serum calcium near the end of gestation averaging around 12 per cent from that of the non-pregnant controls. This was not found in the newly delivered rats or at the end of nursing.

The calcium and phosphorus per gram of body weight, as determined from the ash of the entire carcass, showed a 6 per cent loss near the end of gestation, from that of the non-pregnant controls. Newly delivered rats or those nursing their young to weaning did not show such a loss.

The fall in serum calcium and phosphorus is an indication of the depletion of the body stores, as determined from an analysis of the body ash. The analogous fall in the human during pregnancy can, therefore, also be taken as an indication of the depletion of the mineral stores of the body.

New-born rats showed a much lower calcium and phosphorus content per gram of body weight than the adults, and an entirely different calciumphosphorus ratio.

\section{BIBLIOGRAPHY}

1. Mull, J. W., and Bill, A. H., Variations in serum calcium and phosphorus during pregnancy. I. Normal variations. Am. J. Obst. and Gynec., 1934, 27, 510.

2. Mull, J. W., Bill, A. H., and Kinney, F. M., Variations in serum calcium and phosphorus during pregnancy. II. The effect on the occurrence of dental caries. Am. J. Obst. and Gynec., 1934, 27, 679.

3. Schmidt, C. L. A., and Greenberg, D. M., Occurrence, transport, and regulation of calcium, magnesium, and phosphorus in the animal organism. Physiol. Rev., 1935, 15, 297.

4. Mull, J. W., and Bill, A. H., Calcium and inorganic phosphorus content of prenatal and postpartum serum. Am. J. Obst. and Gynec., 1932, 23, 807.

5. Mull, J. W., and Bill, A. H., The normal range of calcium and inorganic phosphorus in the serum of healthy nonpregnant women. J. Lab. and Clin. Med., 1933, 18, 1034.

6. Peters, J. P., and Van Slyke, D. D., Quantitative Clinical Chemistry. Vol. II. Methods. Williams and Wilkins Co., Baltimore, 1932, p. 873.

7. Macy, I. G., Hunscher, H. A., Nims, B., and McCosh, S. S., Metabolism of women during the reproductive cycle. I. Calcium and phosphorus utilization in pregnancy. J. Biol. Chem., 1930, 86, 17.

8. Goss, H., and Schmidt, C. L. A., Calcium and phosphorus metabolism in rats during pregnancy and lactation and the influence of the reaction of the diet thereon. J. Biol. Chem., 1930, 86, 417.

9. Donelson, E., Nims, B., Hunscher, H. A., and Macy, I. G., IV. Calcium and phosphorus utilization in late lactation and during subsequent reproductive rest. J. Biol. Chem., 1931, 91, 675.

10. Givens, M. H., and Macy, I. G., The chemical composition of the human fetus. J. Biol. Chem., 1933, $102,7$. 